\title{
Does Mental Accounting Play an Important Role in Young Entrepreneurs? Studies on Entrepreneurship Education
}

\author{
Wirawan E.D. Radianto \\ Ika Salim ${ }^{2}$ \\ Sonata Christian ${ }^{3}$ \\ Tommy Christian Efrata ${ }^{4}$ \\ Liliana Dewi ${ }^{4}$ \\ ${ }^{1}$ Department of Accounting, Universitas Ciputra Surabaya, \\ CitraLand CBD Boulevard, Made, Kec. Sambikerep, Kota SBY, \\ Jawa Timur 60219, Indonesia \\ ${ }^{2}$ Research \& Community Development, Universitas Ciputra Surabaya, \\ CitraLand CBD Boulevard, Made, Kec. Sambikerep, Kota SBY, \\ Jawa Timur 60219, Indonesia \\ ${ }^{3}$ Graduate School of Business, Universiti Sains Malaysia, \\ 11800 Gelugor, Penang, Malaysia \\ ${ }^{4}$ Department of Management, Universitas Ciputra Surabaya, \\ CitraLand CBD Boulevard, Made, Kec. Sambikerep, \\ Kota SBY, Jawa Timur 6o219, Indonesia
}

DOI: https://doi.org/10.36941/jesr-2022-004o

\section{Abstract}

The purpose of this study was to examine the role of mental accounting, financial attitude, and financial selfefficacy on financial behavior. Furthermore, this study examines the effect of financial knowledge on mental accounting, financial attitude, and financial self-efficacy. This study uses 400 student respondents who have businesses. Data analysis using PLS. The results show that financial behavior is influenced by mental accounting, financial attitude, and financial self-efficacy. However, financial knowledge did not increase mental accounting and financial self-efficacy. This study proves that mental accounting is very important for student success in business. Mental accounting controls the mindset of young entrepreneurs in managing finances so that they have a positive financial attitude, good financial self-efficacy, and effective financial behavior. From this study, we believe that mental accounting plays an important role for young entrepreneurs in financial decision-making. However, financial knowledge does not necessarily influence the mental accounting mindset.

Keywords: Mental Accounting, financial behavior, financial attitude, financial self-efficacy, financial knowledge 


\section{Introduction}

To date, financial literacy still attracts the attention of governments, businessmen, even researchers because of its relation with people's well-being. Furthermore, the increase of various banking and non-banking sectors' financial products raises the importance of people's financial literacy. With the people's high financial literacy, it is hoped that they will understand these various financial products to use them to increase their well-being. Furthermore, the current advancement of technology creates financial innovations in non-cash payment cards, payment applications, even electronic savings and loan applications. These innovations push individuals to save, invest, and insure quickly and easily. However, suppose these innovations are not pushed with adequate financial knowledge. In that case, the people will not be interested in buying these financial products or will not manage their finances well enough to not optimize the available financial products.

Good financial management is encouraged by a person's behavior related to how they manage their finances in the current time or the future. In addition, financial behavior will influence a person's perception of their life's well-being and how content they are with their economic condition (Saurabh \& Nandan, 2018). Parrey \& Hakeem (2018) and Yong, Yew, \& Wee (2018) find that individuals who have good financial behavior will control their spending, pay their bills in a disciplined manner, and commit to doing financial planning in the future.

Financial Behaviour is not unrelated to several aspects that influence it, such as financial attitude, financial knowledge, and financial self-efficacy, although the interactions between these variables are still inconsistent (Asaff, Suryati, \& Rahmayani, 2019; Çoşkun \& Dalziel, 2020; Faique et al., 2017; Faktor et al., 2020; Ismail et al., 2017, 2020; Kirbis, Vehovec, \& Galic, 2016; Zamri, Bakar, \& Bakar, 2020). Srivastava, Sharma, \& Srivastava (2019) find that the human brain influences financial behavior, especially when making financial decisions. It is as if the brain makes different accounting accounts, which influences decision-making. This difference is due to a psychological aspect known as mental accounting (Hsee \& Kunreuther, 2000). Mental accounting is a cognitive aspect used by individuals and households to control, evaluate, monitor, and track financial activities (Thaler, 1999). This definition states that mental accounting is how a person sees, groups, and treats their finances. A person treats their finances by observing several aspects: the ability to secure his incomes, the currently owned wealth, and the ability to secure incomes in the future. Mental accounting itself is influenced by the person's knowledge and understanding of finance (Shefrin \& Thaler, 1988). From these descriptions, it can be said that mental accounting can be shown by an individual's implementation of accounting principles on his financial activity so that mental accounting will influence financial behavior. However, only a few studies investigate the interaction of mental accounting with financial attitude, financial knowledge, and financial self-efficacy in influencing financial behavior.

This study aims to test the interaction of mental accounting with financial attitude, financial knowledge, and financial self-efficacy in influencing financial behavior. In particular, this study also tests the influence of financial attitude on financial behavior, financial knowledge on financial attitude, financial knowledge on financial self-efficacy, financial knowledge on mental accounting, mental accounting on financial self-efficacy, mental accounting on financial attitude, mental accounting on financial self-efficacy, and financial self-efficacy on financial behavior.

Studies about financial Behaviour have been conducted many times with using students as the sample, both school and university students (Agnew \& Harrison, 2015; Sarigül, 2014; Ibrahim, Harun, \& Isa, 2010, Radianto, Efrata, \& Dewi, 2019; Huston, 2010; Sugiyanto, Radianto, Efrata, \& Dewi, 2019). However, this study is different from the previous ones in that this study uses university students who are taking entrepreneurship studies and already own businesses. Therefore, the respondent criteria in this study are interesting to be studied because they have different characteristics from the ones that are used in previous studies. 


\section{Literature Review and Development of Hypotheses}

Financial Behaviour plays an important part in influencing individuals' well-being in their household, community, and country (Mudzingiri, Muteba, Keyser, \& Nicolaas, 2018). Two internal factors influence financial Behaviour: cognitive ability and psychological factors, whereas external factors include economic and social conditions (Capuano \& Ramsay, 2012). Financial Behaviour is related to how people manage their finances, plan their spending, and secure their income. This study is based on the Theory of Planned Behaviour. This theory explains the connection between faith, Behaviour, will, and financial Behaviour. In addition, this theory explored the relationship between financial knowledge, mental accounting, financial attitude, financial self-efficacy to stimulate financial Behaviour (Ajzen, 2012).

Financial attitude is the state of mind and assessment of an individual's personal finances that are implemented to the attitude to their connection to the finances (Rai, Dua, \& Yadav, 2019). Financial attitudes are important in deciding whether a person successfully manages their finances (Çoşkun \& Dalziel, 2020). Borden, Lee, Serido, \& Collins (2008) and Herdjiono et al. (2016) find that financial attitude influences financial Behaviour, so the first hypothesis is as follows:

$\mathrm{H}_{1}=$ Financial Attitude influences financial Behaviour.

Financial knowledge refers to the knowledge stocks specifically related to understanding the concept and financial products (Huston, 2010). Financial knowledge implies that individuals should have financial knowledge to support financial decision-making. Thus they will act openly on financial information and cannot impulsively consume. A high financial knowledge will result in a high financial attitude; that is, people will behave positively about the future so that they will be able to manage their finances wisely and always be oriented towards the future (Lind et al., 2020). People who have financial self-efficacy have high confidence in managing their finances well. Amanah et al. (2016) find that generally, a high financial knowledge will increase confidence in making financial decisions. People's confidence and Behaviour in managing their finances are based on the level of financial knowledge (Yong et al., 2018). This shows that there is an influence on financial self-efficacy by financial knowledge. Shefrin \& Thaler (1988) and Thaler (1985) stated that individuals' knowledge and understanding of finance include dealing with financial decisions that impact their mental accounting. These descriptions are the basis of the following second, third, and fourth hypotheses.

$\mathrm{H}_{2}=$ Financial knowledge influences financial attitude

$\mathrm{H}_{3}=$ Financial knowledge influences financial self-efficacy

$\mathrm{H}_{4}=$ Financial knowledge influences mental accounting

Individuals' participation in their financial products shows how good they are at managing their private finances, financially responsible, and thinking for the future (Bandura, 1978). Therefore, a higher individuals' confidence in their ability to manage their finances well will impact their Behaviour in managing their finances. Several studies have been conducted before and found that Financial Self-Efficacy influences Financial Behaviour (Farrell, Fry,\& Risse, 2016; Laili Rizkiawati \& Asandimitra, 2018; Serido, Shim, \& Tang, 2013). From these studies, it can be seen that individuals have confidence in their ability to manage their finances better. The following fifth hypothesis is based on this statement, that is:

$\mathrm{H}_{5}=$ Financial self-efficacy influences financial Behaviour

Thaler (1999) defined mental accounting as an economic behavior when someone mentally groups their income and spending based on particular posts or accounts, just as in an accounting model. A person who possesses mental accounting will have the tendency to group their finances in different accounts based on subjective criteria, such as the source of income and the intent of revenue spending (Angle, Konidala, Ujwal, Vishnu, \& Misra, 2019), so mental accounting will influence a person's Behaviour in making their financial decision. According to Silaya \& Persulessy (2017), mental accounting will limit a person's spending. This is due to the mindset of spending posts category and evaluating their spending, which will influence someone's financial Behaviour. Mental accounting always evaluates someone's financial decision (Henderson \& Peterson, 1992). When a person can evaluate their spending 
well, it will raise their confidence in managing their finances, just like managing finances based on several posts that already have their sources and purposes, so that mental accounting focuses on how a person must deal with and evaluate a situation when several possible results are connected with finances. These descriptions are the basis for the next three hypotheses:

$\mathrm{H}_{6}=$ Mental Accounting influences financial attitude

$\mathrm{H}_{7}=$ Mental Accounting influences financial Behaviour

$\mathrm{H}_{8}=$ Mental Accounting influences financial self-efficacy

\section{Research Method}

This research employs a survey method and uses primary data collected using questionnaires. The population of this study is an entrepreneur who is an entrepreneur who is in the process of starting a business. We use the purposive sampling method to collect our sample. There are several criteria for our sample as follows. We use business starting entrepreneurs, have still active businesses, and are willing to fill out questionnaires. The questionnaires were sent to business starting entrepreneurs. We were supported by enumerators that met the respondent candidates in person. 600 questionnaires were successfully distributed. 461 questionnaires were returned, which means it has the return level of $77 \%$, but only 400 questionnaires were filled, or $86.7 \%$ of the returned questionnaires.

The summary of the definition of the operant variables of this research and their indicators are shown in Table 1.

Table 1: Operant Variables Definition

\begin{tabular}{|l|l|l|}
\hline Variable & Indicator & Source \\
\hline $\begin{array}{l}\text { Financial } \\
\text { Knowledge }\end{array}$ & $\begin{array}{l}\text { A person's knowledge in managing their finances to } \\
\text { make financial decisions. }\end{array}$ & $\begin{array}{l}\text { Van Rooij, Lusardi, \& Alessie (2012), } \\
\text { Potrich, Vieira, Coronel, \& Bender } \\
\text { Filho (2015) }\end{array}$ \\
\hline $\begin{array}{l}\text { Financial } \\
\text { Attitude }\end{array}$ & $\begin{array}{l}\text { The judgment, opinion, or state of mind of a person on } \\
\text { finances are applied to their Behaviour. }\end{array}$ & $\begin{array}{l}\text { Potrich, Vieira, Coronel, \& Bender } \\
\text { Filho (2015) }\end{array}$ \\
\hline $\begin{array}{l}\text { Financial Self- } \\
\text { Efficacy }\end{array}$ & A person's confidence in managing their finances well & Lown (2011) \\
\hline $\begin{array}{l}\text { Mental } \\
\text { Accounting }\end{array}$ & $\begin{array}{l}\text { An operational cognitive set that is used to manage, } \\
\text { evaluate, and ensure that one's financial activity is going } \\
\text { according to plan }\end{array}$ & $\begin{array}{l}\text { Shefrin \& Thaler (1988), H. Thaler } \\
\text { (1999) }\end{array}$ \\
\hline $\begin{array}{l}\text { Financial } \\
\text { Behaviour }\end{array}$ & $\begin{array}{l}\text { A person's Behaviour is related to financial } \\
\text { management. }\end{array}$ & $\begin{array}{l}\text { Potrich, Vieira, Coronel, \& Bender } \\
\text { Filho (2015) }\end{array}$ \\
\hline
\end{tabular}

Each indicator shown in Table 1 is stated in the Likert Scale, in which response 1 is for Strongly Disagree and so on until response 7 that is for Strongly Agree. The analysis tool used in this study is Partial Least Square (PLS). PLS is a powerful analysis method because it is not based on assumptions, and it can explain the relations between latent variables (Ghozali, 2013).

\section{Data Analysis}

As mentioned before, in Research Method, 400 pieces of data can be processed and used as the final research sample. The distribution of the demography of the respondents' data is shown in Table 2.

Table 2: Distribution of Research Respondents Demography ( $\mathrm{n}=400)$

\begin{tabular}{|l|l|l|c|c|}
\hline No & Category & Description & Quantity & Percentage \\
\hline \multirow{2}{*}{1} & \multirow{2}{*}{ Sex } & Male & 256 & $64 \%$ \\
& & Female & 144 & $36 \%$ \\
\hline
\end{tabular}




\begin{tabular}{|c|c|c|c|c|}
\hline No & Category & Description & Quantity & Percentage \\
\hline 2 & Age & $\begin{array}{l}<20 \text { years old } \\
20-25 \text { years old } \\
>25 \text { years old }\end{array}$ & $\begin{array}{c}106 \\
212 \\
82 \\
\end{array}$ & $\begin{array}{l}27 \% \\
53 \% \\
21 \% \\
\end{array}$ \\
\hline 3 & Monthly spending & $\begin{array}{l}<5 \text { million } \\
5-10 \text { million } \\
>10 \text { million }\end{array}$ & $\begin{array}{c}280 \\
88 \\
32 \\
\end{array}$ & $\begin{array}{c}70 \% \\
22 \% \\
8 \% \\
\end{array}$ \\
\hline 4 & Ethnicity & \begin{tabular}{|l} 
Javanese \\
Chinese \\
Sundanese \\
Batak \\
Arabic \\
Others \\
\end{tabular} & $\begin{array}{c}130 \\
241 \\
2 \\
1 \\
2 \\
24 \\
\end{array}$ & $\begin{array}{c}32.5 \% \\
60.3 \% \\
0.5 \% \\
0.3 \% \\
0.5 \% \\
6.0 \% \\
\end{array}$ \\
\hline 5 & Business Duration & $\begin{array}{l}<3 \text { years } \\
3-5 \text { years } \\
>5 \text { years }\end{array}$ & $\begin{array}{c}295 \\
70 \\
35\end{array}$ & $\begin{array}{c}74 \% \\
18 \% \\
9 \%\end{array}$ \\
\hline
\end{tabular}

As seen from Table 2, male respondents make up 64\% of the total respondents, while the female respondents make up $36 \%$ of the total. On average, the respondents are young, with 106 respondents less than 20 years old ( $27 \%$ of the respondents) and 212 respondents between 20 to 25 years old ( $53 \%$ of the respondents). The majority of the respondents, 280 respondents, spend less than 5 million monthly (70\% of the respondents). The ethnicities of the respondents are dominated by Javanese, at 130 respondents and Chinese, at 241 respondents (32.5\% and $60.3 \%$ of the respondents), the rest are made up of Sundanese, Batak, Arabic, and other ethnicities. The majority of the respondents have run their business for less than 3 years, at 295 respondents ( $74 \%$ of the respondents). The data from Table 2 show that the characteristics of the respondents in this research are young entrepreneurs that have run their business for less than 3 years, ethnically Javanese and Chinese, with monthly spending of less than 5 million.

\subsection{Descriptive Analysis of the Characteristics of Variables}

Table 3 shows the descriptive analysis for each variable. It is seen in the table that the average respondents' answers for financial attitude are close to the value of 6 or a bit less than 6 . Meanwhile, for financial self-efficacy, mental accounting, and financial Behaviour, the answers are close to the value of 5. These results mean that the respondents' answers agree with the questioned indicators on average.

Table 3: Descriptive Statistic of Research Variables

\begin{tabular}{|l|l|c|c|c|}
\hline No & Variable & $\begin{array}{c}\text { Number } \\
\text { of indicator }\end{array}$ & Average & Standard Deviation \\
\hline $\mathbf{1}$ & Financial Knowledge & 5 & 0.6220 & 0.23887 \\
\hline $\mathbf{2}$ & Financial Attitude & 8 & 6.3710 & 0.82611 \\
\hline 3 & Financial Self Efficacy & 6 & 4.9012 & 0.97781 \\
\hline 4 & Mental Accounting & 9 & 5.0128 & 0.98128 \\
\hline 5 & Financial Behaviour & 9 & 5.5208 & 0.83819 \\
\hline
\end{tabular}

\section{Results}

\subsection{Measurement (Outer) Model Testing}

The first step in measurement model testing is the validity test. An indicator is declared as valid if it has a loading factor of greater than 0.5 on the aimed construct. Smart PLS output for the loading 
factor shows that all indicators have loading factors greater than 0.5. Overall, this means that all validity terms are fulfilled. The following are the detailed descriptions of the validity test results.

The validity test for the reflective indicators uses the correlation between the item score and the construct score. The measurement using the reflective indicators shows that there are changes on the indicators of the constructs if other indicators of the same constructs change (or are eliminated from the model). Reflective indicators are well suited to measure perceptions, so this research uses reflective indicators.

According to Hair et al. (2017), all outer loading indicators with the result that is less than 0.4 will be eliminated immediately, while outer loadings with a score between 0.4 and 0.7 must be considered if they can increase the AVE value and CR above the threshold value. Therefore, in line with Hair et al. (2017), the elimination processes are done in steps.

\subsection{Evaluation of the Measurement Models}

The evaluation of the measurement model for the reflective variables consists of: internal consistency, measured by the $\mathrm{CR}$ value; indicator reliability; convergent validity, measured by the AVE value; and discriminant validity (Hair et al., 2017). In PLS-SEM, individual reliability is more prioritized than the reliability that is measured based on the intercorrelation between the variables in the model. For that, in PLS-SEM, measuring the composite reliability (CR) is seen as more accurate rather than using Cronbach's Alpha (Hair et al., 2017).

Table 4: Composite Reliability

\begin{tabular}{|l|c|}
\hline Variable & CompositeReliability \\
\hline Financial Attitude & 0.883 \\
\hline Financial Behaviour & 0.761 \\
\hline Financial Knowledge & 0.771 \\
\hline Financial Self-Efficacy & 0.880 \\
\hline Mental Accounting & 0.882 \\
\hline
\end{tabular}

From Table 4, it can be seen that the value of the highest is 0.883 is on the financial attitude variable, and the lowest composite reliability value is 0.761 on the financial behavior variable. The CR values between 0.70 and 0.90 can be seen as satisfactory (Nunally \& Bernstein, 1994).

The next step is to perform the Convergent Validity test. To measure convergent validity, every indicator from the variables must be reliable. To measure indicator reliability, the outer loading value should be $>0.708$. However, a value below that threshold can still be considered, as long as the indicator elimination can increase the average variant extracted (AVE) and composite reliability (CR) (Hair et al., 2017). Meanwhile, a value below 0.4 must be eliminated (Hair et al., 2011). In line with those statements, the model has been improved by eliminating several indicators.

The minimum values of most of the outer loadings are $>0.708$. However, there are still several outer loading values that are less than the threshold value. These are allowed as long as the AVE value of each variable is greater than 0.5 . The AVE value is the total average from the square of the loading value of each indicator divided by the number of indicators. The AVE value is used to decide the convergent validity of each variable. A variable is considered as fulfilling the convergent validity requirement if it has the AVE value of $>0.5$.

Table 5: Average Variance Extracted

\begin{tabular}{|l|c|}
\hline Variable & AVE \\
\hline Financial Attitude & 0.558553 \\
\hline Financial Behaviour & 0.517723 \\
\hline
\end{tabular}




\begin{tabular}{|l|c|}
\hline Variable & AVE \\
\hline Financial Knowledge & 0.628002 \\
\hline Financial Self-Efficacy & 0.648669 \\
\hline Mental Accounting & 0.652570 \\
\hline
\end{tabular}

Referring to Table 5, it can be seen that the average AVE value of each variable is greater than 0.5. So, it can be concluded that, on average, the constructs describe the majority of the variants from the indicators.

The last step of the validity testing is Discriminant Validity, which describes how different a construct is present in the research from the other present constructs in the model. The validity here shows that a construct is truly unique in capturing an existing phenomenon and is different from the other constructs in the model. A construct is declared as fulfilling the discriminant validity requirement if its outer loading indicator value is greater than all cross-loading factors from the other constructs. The discriminant validity testing uses the Fornell-Larcker criterion (Hair et al., 2017; Fornell \& Larcker, 1981), which compares the square root of the AVE with the absolute value from the variable correlation value. Therefore, the square root of the AVE value must be greater that the highest variable correlation value.

Table 6: Fornell-Larcker Criterion

\begin{tabular}{|l|c|c|c|c|c|}
\hline Variable & $\begin{array}{c}\text { Financial } \\
\text { Attitude }\end{array}$ & $\begin{array}{c}\text { Financial } \\
\text { Behavior }\end{array}$ & $\begin{array}{c}\text { Financial } \\
\text { Knowledge }\end{array}$ & $\begin{array}{c}\text { Financial } \\
\text { Self-Efficacy }\end{array}$ & $\begin{array}{c}\text { Mental } \\
\text { Accounting }\end{array}$ \\
\hline Financial Attitude & 0.747364 & & & & \\
\hline Financial Behaviour & 0.326208 & 0.719529 & & & \\
\hline Financial Knowledge & 0.109267 & -0.005519 & 0.792465 & & \\
\hline Financial Self-Efficacy & 0.251278 & 0.412518 & 0.063564 & 0.805399 & \\
\hline Mental Accounting & 0.286614 & 0.675208 & -0.035696 & 0.408210 & 0.807818 \\
\hline
\end{tabular}

The diagonal values in Table 6 show the square root of the AVE value. From the table, it can be seen that the square roots of the AVE values are greater than the correlation variable values on the relevant column or row. So, it can be concluded that by using these two testing methods, each construct consistently fulfills the discriminant validity requirement.

\subsection{Evaluation of the Structural Model}

After the estimated model fulfills the Outer Model criteria, the next step is to perform structural (Inner model) testing. According to (Hair et al., 2017), the evaluation of the structural model for the PLS-SEM includes size and significance, coefficients of determination $\left(\mathrm{R}^{2}\right)$, and predictive relevance $\left(\mathrm{Q}^{2}\right)$.

\subsection{Size and Significance of Path Coefficients}

Table 7: Path Coefficient Hypotheses Test

\begin{tabular}{|c|c|c|c|}
\hline Path & Coefficient & $\mathrm{t}$ - Statistics & p-Value \\
\hline Financial Attitude $\rightarrow$ Financial Behaviour $* * *$ & 0.423066 & 2.656019 & 0.0082 \\
\hline Financial attitude ** & 0.091244 & 1.824398 & 0.0688 \\
\hline NS & 0.121815 & 1.209322 & 0.2273 \\
\hline NS & -0.063591 & 0.496721 & 0.6197 \\
\hline Financial Behaviour *** & 0.242349 & 3.025683 & 0.0026 \\
\hline Financial attitude ${ }^{* * *}$ & 0.124520 & 5.708730 & 0.0000 \\
\hline Financial Behaviour *** & 0.852271 & 13.471601 & 0.0000 \\
\hline$* * *$ & 0.359230 & 8.007992 & 0.0000 \\
\hline
\end{tabular}


$\mathrm{H}_{1}, \mathrm{H}_{2}, \mathrm{H}_{5}, \mathrm{H}_{6} \mathrm{H}_{7}$ dan $\mathrm{H}_{8}$ are proven, but coefficients of determination $\left(\mathrm{R}^{2}\right)$, predictive relevance $\left(\mathrm{Q}^{2}\right)$. It can be seen in Table 8 that in general, the $\mathrm{R}^{2}$ value is in the range of close to 0.5 to close to 0 .

Table 8: Outer Model Testing

\begin{tabular}{|l|c|c|}
\hline Variable & $\mathbf{R}^{2}$ & $\mathbf{Q}^{2}$ \\
\hline Financial Attitude & 0.096 & 0.043793 \\
\hline Financial Behaviour & 0.492 & 0.236004 \\
\hline Financial Knowledge & & 0.013126 \\
\hline Financial Self-Efficacy & 0.172 & 0.104027 \\
\hline Mental Accounting & 0.001 & -0.000943 \\
\hline
\end{tabular}

Table 8 indicates that, excepting the Mental Accounting variable, the other variables' $\mathrm{Q}^{2}$ value is greater than o, so this result supports the existence of the predictive relevance of the model on the endogenous variable. On the Financial Behaviour variable (exogenous variable), the $\mathrm{Q}^{2}$ value is 0.236 or greater than $\mathrm{o}$, which means that there is a predictive relevance on the structural model.

\section{Discussion}

Financial Attitude influences financial Behaviour. A person who has the right Behaviour on finance influences how they manage their money and how they make decisions about the finances. A person who feels that managing their finances is important will act carefully in spending their money. For example, when a person feels that controlling their spending is important, they would compare the prices and check their finances when they are shopping. The greater the financial attitude of a person, the greater their financial Behaviour will be. That means the right Behaviour in managing finances will improve a person's skill in managing their money. This study supports those conducted by Çoşkun \& Dalziel (2020), Borden, Lee, Serido, \& Collins (2008), and Herdjiono et al. (2016).

Financial knowledge positively influences financial attitude. A person's ability to understand finance will make them have the right behavior to manage and purpose their finances. The greater the financial knowledge, the greater the financial attitude. A person who has good knowledge about stock investment will tend to rationally think that stocks are very important as a medium for future investment. Likewise, if a person understands the functions and benefits of saving, it will influence them to regularly saving their money as a backup. This study supports a previous study done by Huston (2010), that a person with financial understanding will be able to make financial decisions. This study also confirms a study done by Lind et al. (2020), which finds that financial knowledge influences financial attitude.

However, this study finds that financial knowledge does not influence financial self-efficacy or mental accounting. The understanding and the level of financial knowledge do not ensure a person is confident in their ability to manage their finances. (Prihartono \& Asandimitra, 2018; Herdjiono, Damanik, \& Musamus, 2016; Lianto \& Elizabeth, 2017). A person with financial knowledge cannot be used as a benchmark to determine whether they have good financial behavior, as discovered by previous studies (Rizkiawati \& Asandimitra, 2018; Armilia \& Isbanah, 2019; Hendra, Yohana, \& Herlina, 2019). In this study's findings, it seems that although the respondents are knowledgeable in finance, due to a relatively young age factor, they are probably unconfident in their ability to fulfill their needs. Even more so, if their businesses are not yet established, they will be worried about not fulfilling their needs. This can be expected from the relatively short lifetime of the respondents' businesses, mostly less than 3 years ( $74 \%$ of the respondents), which means those businesses are still stubs, as seen from Table 2 . This proves that financial knowledge does not always form respondents' self-efficacy. It seems that the relatively young age of the majority of the respondents are still not able to exert self-control on their spending although they have good financial knowledge. Likewise, the financial knowledge they have does not ensure they will be disciplined in monitoring their finances, 
for example, recording their finances and managing their finances with discipline. This could cause financial knowledge to not influence mental accounting. These two new findings contribute to the study about financial knowledge, which are that the entrepreneurs' age and the duration of their businesses are not able to optimise their financial knowledge to form financial self-efficacy and influence their mental accounting.

Financial self-efficacy influences financial Behaviour. Financial efficacy, which is the confidence that a person will be able to manage their finances, is proven in this study. A higher level of confidence in their ability to manage their finances will enable them to make the right financial decision. For example, when a financial emergency happens, they will be confident in fulfilling what that emergency needs so that they will spend wisely, which is to fulfill their needs first and not their wants. Likewise, suppose a person has a high financial self-efficacy when they have financial debt. In that case, those debts will not disturb their cash flow, so they can spend their money wisely and put aside some of their income as an emergency fund or even put their investments in the best investment products. This finding supports several previous findings that financial self-efficacy influences financial behavior (Farrell, Fry, \& Risse, 2016; Serido, Shim, \& Tang, 2013).

This study finds that mental accounting interacts positively with financial attitude, financial behavior, and financial self-efficacy, so all three hypotheses are accepted. This study manages to prove that mental accounting influences a person's behavior in making financial decisions. The more mental accounting a person has, the better their behavior on the right financial management. The more mental accounting influences a person's way of thinking, the better the person in making the right financial decisions. This finding supports CFP Board, Zhang, \& Sussman (2018) who found that mental accounting can influence someone's behavior in selecting what kind of investments suit them. For example, when a person rationally thinks that recording their spending routinely is important, he will monitor his spending every month. As a result, he will be more careful in making financial decisions such as shopping, investing, borrowing, and even saving. This study supports the study by Silaya \& Persulessy (2017). Mental accounting influences a person in increasing their confidence that they can manage their finances well. A person who has mental accounting will feel uncomfortable if they do not make financial plans. Through disciplined and measured financial planning they will be more confident that their future will be prosperous. This study supports the findings of Henderson \& Peterson (1992). One of the important aspects of mental accounting is self-control. The tighter the self-control of a person, the better they will be in controlling their finances (financial attitude). They will also be better in restraining themselves from buying things that are not included as needs (financial Behaviour). They are very confident that the saving they are doing will help them in achieving a prosperous future (self-efficacy). This finding will be an addition from this study, which is mental accounting influences financial attitude and financial self-efficacy, which have been rarely researched in the past.

\section{Conclusion}

This study aims to test the influence of mental accounting, financial attitude, financial knowledge, and financial self-efficacy on the financial Behaviour of university students that are already starting their businesses. The uniqueness of this study compared to the previous ones are the respondents playing the part of a student and a businessperson. The total of the processable questionnaires is 400 questionnaires, with the business-owning respondents are mostly younger than 25 years old and having run their business for less than 3 years. The result of this study shows that financial attitude and financial self-efficacy influence financial behavior, mental accounting influence financial selfefficacy, financial attitude, and financial Behaviour, and financial behavior influence financial attitude. Meanwhile, financial knowledge does not influence financial attitude and mental accounting.

The contribution of this study is especially on the part that mental accounting plays that is proven to influence self-efficacy, financial Behaviour, and financial attitude. In this case, the process 
of mental accounting thinking increases the confidence of a person in managing their finances well. Mental accounting improves the quality of financial decision-making to enable someone to solve their financial problems. This study contributes to the theory of planned Behaviour, especially in the context of financial attitude and financial Behaviour. A person's financial behavior can be explained by managing financial information using his mental accounting. Self-control and mental budgeting, an important part of mental accounting, will limit and influence one's decision-making.

The limitation of this study is that it does not correlate the family background of the respondents. Different family backgrounds will surely influence the respondents' financial Behaviour. This will also open a new opportunity for the next study. The next study also can be done by filling the research gap of this study, which is that there is a chance of the existence of mediating variables between financial knowledge with financial self-efficacy and mental accounting. This study does not yet include the factor of mental accounting bias, so that it is hoped that the next study can include that aspect.

\section{References}

Agnew, S., \& Harrison, N. (2015). Financial literacy and student attitudes to debt: A cross national study examining the influence of gender on personal finance concepts. Journal of Retailing and Consumer Services, 25, 122129. https://doi.org/10.1016/j.jretconser.2015.04.006

Ajzen, I. (2012). The theory of planned behavior. Handbook of Theories of Social Psychology: Volume 1, 211, 438459. https://doi.org/10.4135/9781446249215.n22

Amanah, E., Rahadian, D., \& Iradianty, A. (2016). Pengaruh Financial Knowledge, Financial Attitude dan External Locus Of Control Terhadap Personal Financial Management Behavior Pada Mahasiswa S1 Universitas Telkom [The Influence of Financial Knowledge, Financial Attitude and External Locus of Control on Personal Financial Management Behaviour on Bachelor Degree Students in Universitas Telkom]. In eProceedings of Management (Vol. 3).

Angle, P., Konidala, S., Ujwal, D., Vishnu, B., \& Misra, S. (2019). Impact of Mental Accounting Bias on Stock Market Integration. Journal of Xian University of Architecture and Technology, 11(12), 283-304.

Asaff, R., Suryati, \& Rahmayani, R. (2019). Pengaruh Financial Attitude dan Financial Knowledge terhadap Financial Management Behavior (Studi Kasus pada Mahasiswa Fakultas Ekonomi Konsentrasi Keuangan Universitas Andi Djemma Palopo) [The Influence of Financial Attitude and Financial Knowledge on Financial Management Bevahiour (A Case Study on Bachelor Degree Students of Faculty of Economic Finance Major of Universitas Andi Djemma Palopo ]. Jurnal of Economic, Management and Accounting, 2(2), 68-74.

Bandura, A. (1978). Self-efficacy: Toward a unifying theory of behavioral change. Advances in Behaviour Research and Therapy, 1(4), 139-161. https://doi.org/10.1016/o146-6402(78)900o2-4

Borden, L. M., Lee, S. A., Serido, J., \& Collins, D. (2008). Changing college students' financial knowledge, attitudes, and behavior through seminar participation. Journal of Family and Economic Issues, 29(1), 23-40. https://doi.org/10.1007/s10834-007-9087-2

Capuano, A., \& Ramsay, I. (2012). What Causes Suboptimal Financial Behaviour? An Exploration of Financial Literacy, Social Influences and Behavioural Economics. SSRN Electronic Journal, (540). https://doi.org/10.2139/ssrn.1793502

CFP Board, Zhang, C. Y., \& Sussman, A. B. (2018). The Role of Mental Accounting in Household Spending and Investing Decisions. Client Psychology. https://doi.org/10.1002/9781119440895.ch6

Çoşkun, A., \& Dalziel, N. (2020). Mediation effect of financial attitude on financial knowledge and financial behavior. International Journal of Research in Business and Social Science (2147- 4478), 9(2), o1-08. https://doi.org/10.20525/ijrbs.v9i2.647

Faique, F. A., Ismail, S., Bakri, M. H., Idris, N. H., Yazid, Z. A., Daud, S., \& Taib, N. M. (2017). Testing the financial attitude as a mediator for the relationship between financial self-efficacy with financial behavior. Advanced Science Letters, 23(8), 8009-8012. https://doi.org/10.1166/asl.2017.9632

Faktor, A., Memengaruhi, Y., Management, F., Dengan, B., Locus, M., \& Control, O. F. (2020). Analisis faktor yang memengaruhi financial management behavior dengan mediasi locus of control [Analysing Factors that Affects Financial Management Behaviour with Locus of Control as the Mediating Factor], 8, 549-563.

Farrell, L., Fry, T. R. L., \& Risse, L. (2016). The significance of financial self-efficacy in explaining women's personal finance behavior. Journal of Economic Psychology, 54, 85-99. https://doi.org/10.1016/j.joep.2015.07.001 
Henderson, P. W., \& Peterson, R. A. (1992). Mental accounting and categorization. Organizational Behavior and Human Decision Processes, 51(1), 92-117. https://doi.org/10.1016/o749-5978(92)90oo6-S

Herdjiono, I., Damanik, L. A., \& Musamus, U. (2016). Pengaruh Financial Attitude, Financial Knowledge, Parental Income Terhadap Financial Management Behavior [The Influence of Financial Attitude, Financial Knowledge, Parental Income on Financial Management Behaviour]. Manajemen Teori Dan Terapan, 1(3), 226-241. https://doi.org/10.20473/jmtt.v9i3.3077

Hsee, C. K., \& Kunreuther, H. C. (2000). The Affection Effect in Insurance Decisions. Journal of Risk and Uncertainty, 20(2), 141-159. https://doi.org/10.1023/A:1007876907268

Huston, S. J. (2010). Measuring Financial Literacy. Journal of Consumer Affairs, 44(2), $296-316$. https://doi.org/10.1111/j.1745-6606.2010.01170.X

Ibrahim, D. I. D., Harun, R., \& Isa, Z. M. (2010). A study on financial literacy of Malaysian degree students. CrossCultural Communication, 5(4), 51-59. https://doi.org/10.3968/j.ccc.1923670020090504.006

Ismail, S., Faique, F. A., Bakri, M. H., Zain, Z. M., Idris, N. H., Yazid, Z. A., ... Taib, N. M. (2017). The role of financial self-efficacy scale in predicting financial behavior. Advanced Science Letters, 23(5), 4635-4639. https://doi.org/10.1166/asl.2017.8992

Ismail, S., Koe, W.-L., Halim Mahphoth, M., Abu Karim, R., Yusof, N., \& Ismail, S. (2020). Saving Behavior Determinants in Malaysia: An Empirical Investigation. KnE Social Sciences, 2020, $731-743$. https://doi.org/10.18502/kss.v4i6.6639

Kirbis, I. Š., Vehovec, M., \& Galic, Z. (2016). Relationship Between Financial Satisfaction and Financial Literacy: Exploring. Drus Istraz Zagreb God, 26(2), 165-185.

Laili Rizkiawati, N., \& Asandimitra, N. (2018). Pengaruh Demografi, Financial Knowledge, Financial Attitude, Locus of Control Dan Financial Self-Efficacy Terhadap Financial Management Behavior Masyarakat Surabaya [The Influence of Demography, Financial Knowledge, Financial Attitude, Locus of Control and Financial Self-Efficacy on Financial Management Bevahiour of the People of Surabaya]. Jurnal Ilmu Manajemen (JIM), 6(3), 93-107.

Lind, T., Ahmed, A., Skagerlund, K., Strömbäck, C., Västfjäll, D., \& Tinghög, G. (202o). Competence, Confidence, and Gender: The Role of Objective and Subjective Financial Knowledge in Household Finance. Journal of Family and Economic Issues, (o123456789), 1-13. https://doi.org/10.1007/s10834-020-09678-9

Lown, J. M. (2011). Development and validation of a financial self-efficacy scale. Journal of Financial Counseling and Planning, 22(2), 54 .

Micrets Agustina, S., \& Grace, P. (2013). Mental accounting Dan Faktor Demografi: Fenomena Penggunaan Kartu Kredit Pada Pegawai Bank Danamon Cabang Ambon Micrets [Mental Accounting and Demography Factor: The Phenomenon of Credit Cards Usage of the Employee of Ambon Branch of Bank Danamon Micrets]. Jurnal Bina Nusantara, 1(1), 39-50.

Mudzingiri, C., Muteba, M., Keyser, J. W., \& Nicolaas, J. (2018). Financial behavior, confidence, risk preferences and financial literacy of university students. Cogent Economics and Finance, 6(1), 1-25. https://doi.org/10.1080/23322039.2018.1512366

Parrey, S. H., \& Hakeem, I. A. (2018). Financial Knowledge and Financial Behaviour of Agri-Allied Entrepreneurs: A Mediational Study of Cultural Values. Sankalpa, 8(2), 1-11.

Potrich, A. C. G., Vieira, K. M., Coronel, D. A., \& Bender Filho, R. (2015). Financial literacy in Southern Brazil: Modeling and invariance between genders. Journal of Behavioral and Experimental Finance, 6, 1-12. https://doi.org/10.1016/j.jbef.2015.03.002

Radianto, W. E. D., Efrata, T. C., \& Dewi, L. (2019). Level of Financial Literacy in Young Entrepreneurs: Study on Entrepreneurship-based University. In KnE Social Sciences (pp. 385-398).

Rai, K., Dua, S., \& Yadav, M. (2019). Association of Financial Attitude, Financial Behaviour and Financial Knowledge Towards Financial Literacy: A Structural Equation Modeling Approach. FIIB Business Review, 8(1), 51-6o. https://doi.org/10.1177/2319714519826651

Sarigül, H. (2014). A Survey of Financial Literacy Among University Students. Journal of Accounting \& Finance, (64), 207-224.

Saurabh, K., \& Nandan, T. (2018). Role of financial risk attitude and financial behavior as mediators in financial satisfaction: Empirical evidence from India. South Asian Journal of Business Studies, 7(2), $207-224$. https://doi.org/10.1108/SAJBS-07-2017-0088

Serido, J., Shim, S., \& Tang, C. (2013). A developmental model of financial capability: A framework for promoting a successful transition to adulthood. International Journal of Behavioral Development, 37(4), $287-297$. https://doi.org/10.1177/o165025413479476

Shefrin, H. M., \& Thaler, R. H. (1988). The behavioral life-cycle hypothesis. Economic Inquiry, 26(4), 6o9-643. https://doi.org/https://doi.org/10.1111/j.1465-7295.1988.tbo1520.x 
Silaya, M. A., \& Persulessy, G. (2017). Mental accounting Dan Faktor Demografi: Fenomena Penggunaan Kartu Kredit Pada Pegawai Bank Danamon Cabang Ambon [Mental Accounting and Demography Factor: The Phenomenon of Credit Cards Usage of the Employee Of Ambon Branch of Bank Danamon]. Jurnal Soso-Q, 5(1), 57-67. https://doi.org/10.30598/sosoq.v5i1.112

Srivastava, M., Sharma, G. D., \& Srivastava, A. K. (2019). Human brain and financial behavior: a microfinance perspective. International Journal of Ethics and Systems, 35(4), 485-503. https://doi.org/10.1108/IJOES-022019-0036

Sugiyanto, T., Radianto, W. E. D., Efrata, T. C., \& Dewi, L. (2019). Financial Literacy, Financial Attitude, and Financial Behavior of Young Pioneering Business Entrepreneurs. In 2019 International Conference on Organizational Innovation (ICOI 19) (pp. 353-358). Atlantis Press. https://doi.org/10.2991/icoi-19.2019.60

Thaler, R. (1985). Mental accounting and consumer choice. Marketing Science, 4(3), 199-214. https://doi.org/https://doi.org/10.1287/mksc.4.3.199

Thaler, R. H. (1999). Mental accounting matters. Journal of Behavioral Decision Making, $12(3), 183-206$. https://doi.org/https://doi.org/10.1002/(SICI)1099-0771(199909)12:3<183::AID-BDM318>3.o.CO;2-F

Van Rooij, M. C. J., Lusardi, A., \& Alessie, R. J. M. (2012). Financial literacy, retirement planning and household wealth. The Economic Journal, 122(56o), 449-478. https://doi.org/10.1111/j.1468-0297.2012.02501.X

Yong, C.-C., Yew, S.-Y., \& Wee, C.-K. (2018). Financial knowledge, attitude and Behaviour of young working adults in Malaysia. Institutions and Economies, $10(4), 21-48$.

Zamri, M., Bakar, A., \& Bakar, S. A. (2020). Prudent Financial Behaviour among Youth : The Role of Financial Attitude, (8), 30-34. https://doi.org/10.35940/ijmh.Ho765.044820

Zhao, X., Lynch, J. G., and Chen, Q. (2010). Reconsidering Baron and Kenny: Myths and Truths About Mediation Analysis. Journal of Consumer Research, 37(2), 197-206. 